\title{
SACRUM - PROFANUM. DWA ŻYWOTY MISY MOSIĘŻNEJ Z SANTOKA
}

\author{
THE SACRED AND THE PROFANE. \\ TWO LIVES OF A BRASS BOWL FROM SANTOK
}

\begin{abstract}
The article presents the results of interpretation of a part of a brass bowl unearthed in 1958 in the course of millennial excavations in Santok. An engraved ornament is visible on one of the surfaces of the sheet, the most important part of which is an outline of a bust with a head in a hat shown in profile. Three Latin characters allow to identify the image as a personification of Envy (Invidia), while the sheet itself is a fragmented, so called brass bowl representing deadly sins. The vessel were forged in Rhineland and might have been originally used for liturgical ceremonies in St. Andrew's church and its fragmented part was uncovered in the context of a smithy as a recycled material.
\end{abstract}

Keywords: Santok, Early Middle Ages, blacksmith's workshop, brass bowl.

\section{WSTĘP}

Wczesnośredniowieczny gród w Santoku należał do jednych z ważniejszych ośrodków w państwie piastowskim (ryc. 1). Wyróżniało go charakterystyczne położenie w Pradolinie Toruńsko-Eberswaldzkiej spajającej Pomorze z Wielkopolską, w widłach rzek Warty i Noteci, zapewniających dostęp drogami wodnymi zarówno do sąsiednich, jak i odległych regionów (ryc. 1). Wprawdzie Santok leżał z dala od centralnych obiektów Piastów skupiających się w środkowej Wielkopolsce, jednak rozwijał się niezwykle intensywnie już dużo wcześniej, bo od drugiej połowy VIII stulecia. Funkcjonował wówczas jako faktoria handlowa na szlaku rzecznym łączącym wybrzeże Bałtyku z interiorem. Właśnie walory wynikające z położenia w dogodnym miejscu wykorzystali pierwsi mieszkańcy tego miejsca i to one zde-

\footnotetext{
* Instytut Archeologii i Etnologii PAN Ośrodek Archeologii Średniowiecza Krajów Nadbałtyckich, ul. Kuśnierska 12/12a, 70-536 Szczecin, a.janowski@iaepan.szczecin.pl;

** Instytut Archeologii i Etnologii PAN Ośrodek Studiów Pradziejowych i Średniowiecznych, ul. Rubież 46, 61-612 Poznań, kinga.zamelska@iaepan.poznan.pl.
} 


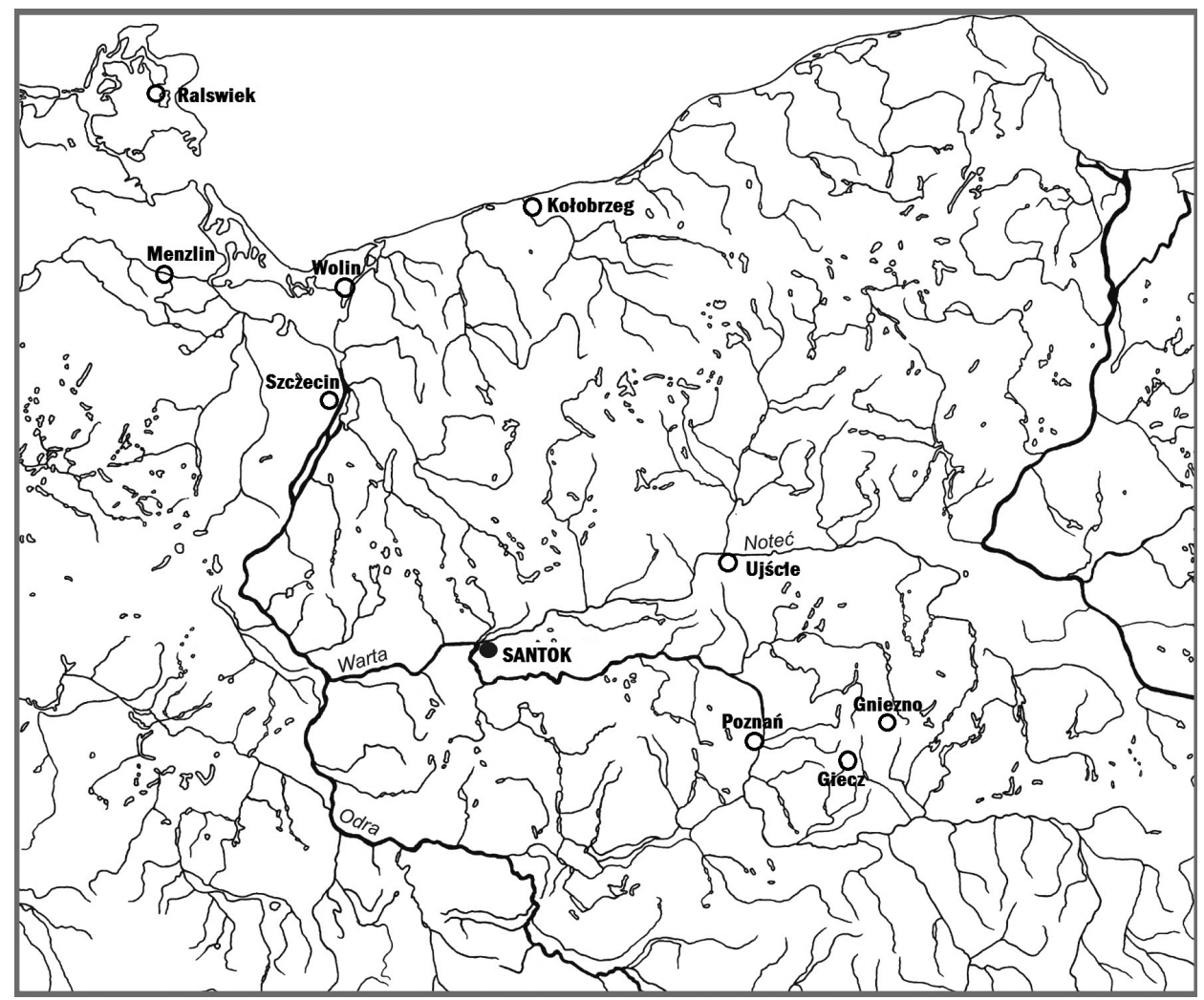

Ryc. 1. Lokalizacja Santoka (opr. K. Zamelska-Monczak)

cydowały o nadrzędnej funkcji ośrodka w Santoku w pierwszym okresie funkcjonowania. Jedna z największych zmian miała miejsce w X w., gdy Santok został włączony w struktury pierwszego państwa piastowskiego, czego najbardziej widomym znakiem była rozbudowa umocnień oraz obwałowanie osiedla, co uczyniło z niego także obiekt o znaczeniu militarnym. Stał się ważnym centrum administracyjnym, handlowym, militarnym, a także religijnym regionu. W ciągu następnych stuleci zmieniało się rozplanowanie grodu i pojawiały się nowe obiekty. Na podstawie źródeł pisanych można wnioskować, że w XII w. w obrębie umocnień grodowych funkcjonował kościół pw. św. Andrzeja oraz mieściła się siedziba kasztelana santockiego. Po przejęciu grodu przez Brandenburczyków w 1296 r. i przesiedleniu mieszkańców podgrodzia osadnictwo skupiło się głównie w jego północnej części, gdzie wzniesiono drewnianą, a następnie kamienno-ceglaną wieżę wraz z zapleczem gospodarczym. Obszar dawnego grodu santockiego był użytkowany do XV wieku.

Dobrze do dziś zachowane grodzisko było miejscem badań archeologicznych prowadzonych najpierw przez badaczy niemieckich (regularne badania wykopaliskowe 


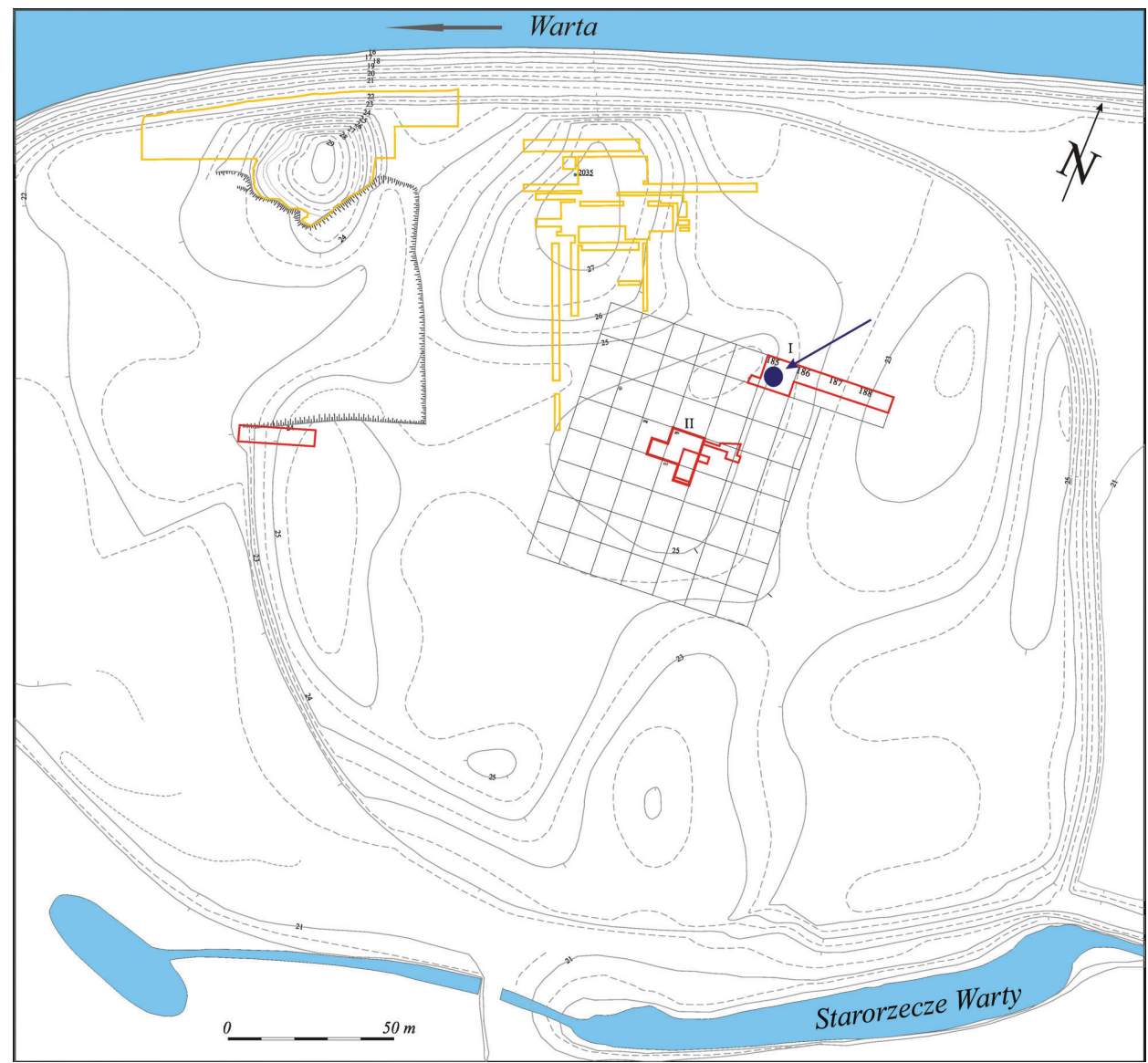

Ryc. 2. Santok. Lokalizacja znaleziska misy w siatce wykopów (opr. K. Zamelska-Monczak)

grodu w Santoku w latach 1932-1934), a następnie ekspedycję wykopaliskową zorganizowaną przez Instytut Historii Kultury Materialnej PAN w ramach badań nad początkami państwa polskiego. Pracami w terenie (lata 1958-1965) kierowali Zofia Hołowińska i Aleksander Dymaczewski. Objęły one wnętrze tzw. wewnętrznego gro$\mathrm{du}$, jego umocnienia oraz strefę podgrodzia w części wschodniej stanowiska.

W roku 1958 w wykopie zlokalizowanym na terenie podgrodzia (ar 185/ćwiartka A, świadek E), w warstwie Ib2, znaleziono fragment blachy ze stopu miedzi z zachowanym rytym ornamentem na jednej z powierzchni (nr inw. 234/58) ${ }^{1}$, będący częścią naczynia - misy. Zabytek zalegał w ciemnobrązowej próchnicy

${ }^{1}$ We wcześniejszych publikacjach znaleźć można informacje odmiennie lokalizujące to znalezisko: warstwa II (V poziom osadniczy) - por. Dymaczewski 1975, Abb. 2; VI poziom osadniczy z początku XIV w. - por. Hensel i Kurnatowska 1987, tabela. 
z wkładkami gliniastymi koloru żółto-pomarańczowego, na głębokości około $0,35 \mathrm{~m}$ pod powierzchnią gruntu (ryc. 2). Występowały w niej również zwały przepalonej gliny oraz duża ilość żużla. Warstwa ta została wyróżniona w miejscu kulminacji dawnego drewniano-ziemnego wału oddzielającego gród wewnętrzny od podgrodzia, który prawdopodobnie już od końca XIII w. podlegał stopniowej niwelacji i nie pełnił swojej pierwotnej funkcji. W obrębie wspomnianej warstwy Ib2 zarejestrowano obecność pieca oraz podwaliny budynku drewnianego, interpretowane jako pozostałości warsztatu kuźniczego.

Informacja na temat znalezienia $\mathrm{w}$ Santoku fragmentu misy ze stopu miedzi znalazła się w literaturze fachowej (por. Hołowińska 1961, ryc. 19; Dymaczewski 1975, Abb. 2; Hensel i Hilczer-Kurnatowska 1987, tab. 1), przeszła jednak w zasadzie bez echa. Tymczasem bliższe oględziny sugerują, że zabytek ten zasługuje na podjęcie odrębnych studiów.

\section{OPIS ZNALEZISKA}

Zachowany fragment misy wykonany jest z blachy o grubości $0,8-1,0 \mathrm{~mm}$ i ma w przybliżeniu kształt trapezu. Jego długość wynosi $103 \mathrm{~mm}$, maksymalna szerokość $48,8 \mathrm{~mm}$, a waga to $23,1 \mathrm{~g}$. Wszystkie główne krawędzie noszą wyraźne ślady odcinania (ryc. 3). Wyniki analiz chemicznych wykazały, że blacha wykonana została ze stopu, którego głównymi komponentami oprócz miedzi $(\mathrm{Cu}-88,16 \%)$ są cynk $(\mathrm{Zn}-8,09 \%)$ i cyna ( $\mathrm{Sn}-2,41 \%)$, przy znikomym, zaledwie jednoprocentowym udziale pozostałych składników ( $\mathrm{Sb}-0,41 \%$, $\mathrm{As}-0,25 \%, \mathrm{~Pb}-0,22 \%$, $\left.\mathrm{Fe}-0,18 \%, \mathrm{Al}-0,10 \%, \mathrm{Au}-0,07 \%, \mathrm{Ti}-0,06 \%, \mathrm{Ag}-0,05 \%{ }^{2}\right)$. Pod względem składu chemicznego stop ten zaliczyć należy zatem do mosiądzów cynowych. Problemem pozostaje $\mathrm{w}$ tym przypadku właściwe stosowanie nazwy mosiądz, ten jest bowiem stopem miedzi z cynkiem metalicznym, a taki zaczęto dodawać do stopów dopiero w XVIII wieku. W średniowieczu stop o składzie takim, jak stwierdzony w misie santockiej, nosił nazwę aurichalcum, a źródłem cynku nie był metaliczny pierwiastek, jak w stopach nowożytnych, ale galman (ruda cynku), który wykorzystywano do cementacji miedzi. Receptura jego wytwarzania znana i powszechnie stosowana była co najmniej od czasów rzymskich (por. m.in. Wołosz 1995, s. 111; Droberjar i Frána 2004, s. 442-446).

Ocena składu chemicznego mis z X-XIII w. wykonanych ze stopów miedzi nie należy do zbyt często przeprowadzanych analiz. Dostępne dane są jednak na tyle liczne, że pozwalają zorientować się, iż struktura stosowanych stopów była bardzo zróżnicowana. Zawartość poszczególnych składników znacząco się wahała w przypadku cynku nawet w przedziale od 1 do $24 \%$, a w przypadku cyny od

\footnotetext{
${ }^{2}$ Analizę składu chemicznego wykonało Laboratorium Bio- i Archeometrii PAN w Warszawie (zlecenie 1135/13, analiza nr CL18297).
} 
1 do $10 \%$. Receptura aurichalcum opisana na przełomie XI i XII w. przez benedyktyńskiego mnicha o pseudonimie Theophil ${ }^{3}$ zawierała jedną część galmanu i pięć części miedzi (por. Teofil 1998, s. 120), czyli w przybliżeniu około 83-84\% miedzi i 16-17\% cynku. Wyniki analiz pokazują, że była to tylko jedna z licznych możliwości (por. Werner 1977; 1981). W związku z powyższym trudno wysuwać wnioski o charakterze ogólnym, próbować wskazać miejsca produkcji czy poszczególne warsztaty wyłącznie na podstawie składu chemicznego stopu zastosowanego do wyrobu naczynia (por. Müller 2006, s. 126-127).

\section{SACRUM - ŻYWOT PIERWSZY}

Jak wspomnieliśmy wcześniej, na jednej z powierzchni blaszki czytelny jest skomplikowany ornament ryty (ryc. 3). U dołu centralne miejsce zajmuje popiersie z głową ukazaną z profilu, nakrytą kapeluszem. Rysy twarzy i włosy przedstawiono schematycznie. Nad prawym ramieniem postaci widoczne są dwie litery łacińskie V oraz I, a nad lewym kolejna - najpewniej D. Od góry popiersie i inskrypcję otacza półkoliście podwójna linia sznurowa. Powyżej czytelne są grupy pionowych i łukowatych linii rytych, zgrupowanych niekiedy po trzy lub cztery, a w lewym narożniku kolejna litera (D?). Według wszelkiego prawdopodobieństwa widoczne w centrum litery to fragment słowa [IN]VID[IA], czyli ZAZDROŚĆ. Pozwala to, pomimo fragmentarycznego stanu zachowania, zidentyfikować ułamek naczynia z Santoka jako część dna i ścianki misy zdobionej przedstawieniem występków.

Misy brązowe ${ }^{4}$ to płytkie naczynia o średnicy na ogół około $25-35 \mathrm{~cm}$ i głębokości 5-8 cm wykonywane z blachy metodą kucia. Sposób ich produkcji był zbliżony do opisanego przez wspominanego już mnicha Theopila w dziele Diversarum artium schedula. W pierwszym etapie odlewano z metalu krążek, który następnie odkuwano dla uzyskania blachy odpowiedniej grubości. Kiedy osiągnął on pożądaną wielkość, nanoszono na nim za pomocą cyrkla współśrodkowe okręgi, które odpowiadały miejscom załamania profilu przyszłego naczynia, a tak przygotowany krążek kuto następnie, rozpoczynając od brzegu i kierując się ku środkowi. W miarę wyklepywania wzrastała głębokość naczynia. W końcowym etapie powierzchnię wykańczano za pomocą skrobaka (Teofil 1998, s. 71-74; por. także Richter 1951, s. 12; Trotzig 1991, s. 67-77, fig. 54). Badacze dość jednomyślnie lokalizują produkcję mis zdobionych na obszarze nadreńskim, znanym z wyrobu

\footnotetext{
3 Według niektórych badaczy pod pseudonimem tym ukrywa się westfalski mnich-złotnik Roger z Helmarshausen (por. Dodwell 1961; Freise 1981).

${ }^{4}$ Mimo iż misy wykonywano ze stopów miedzi o różnym składzie, w literaturze przyjęło się jednak nazywanie ich brązowymi (niem. Bronzeschale) lub hanzeatyckimi (niem. Hanseschale).
} 

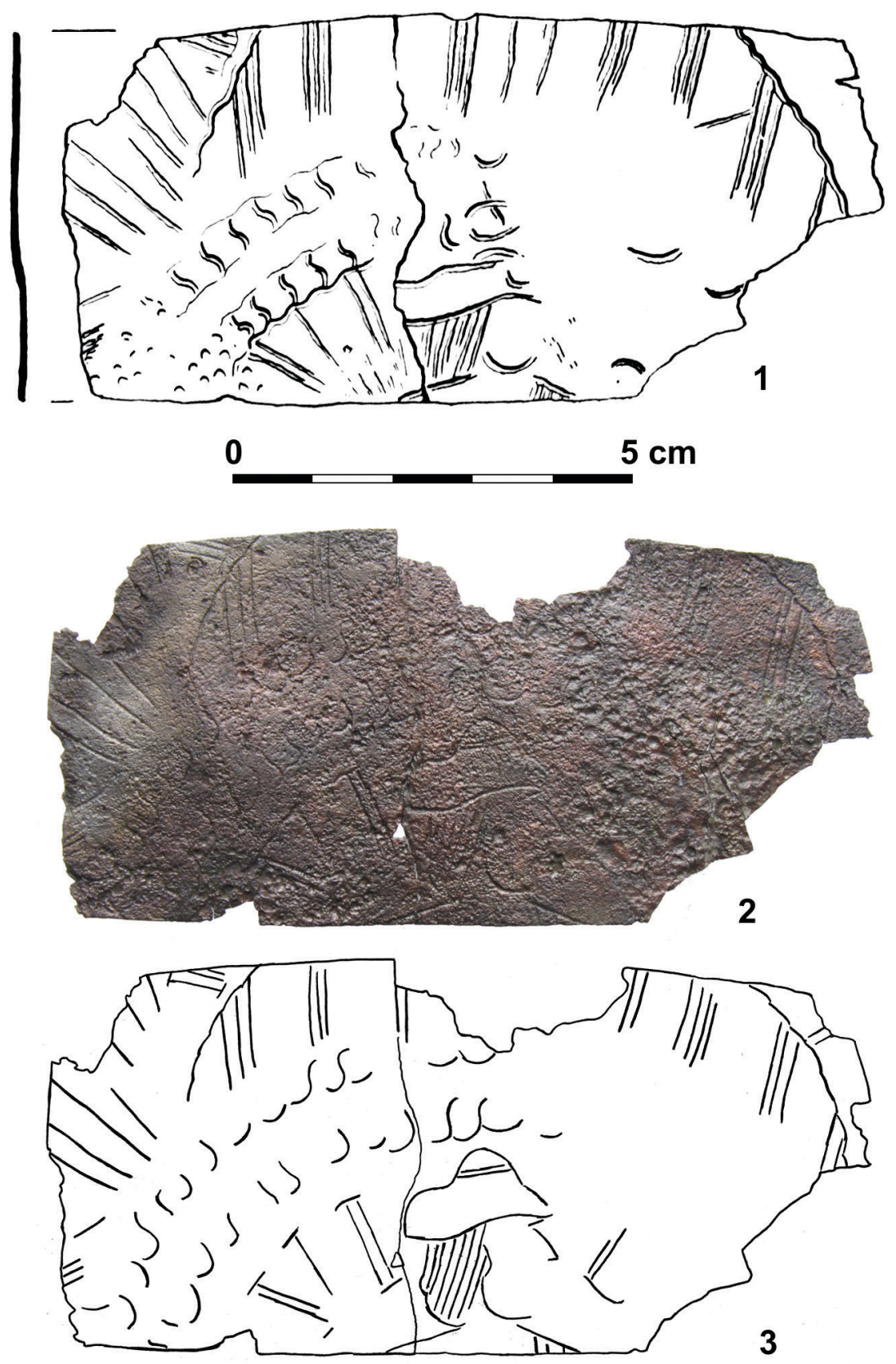

Ryc. 3. Fragment misy z Santoka. 1 - rysunek z 1961 r. (wg Hołowińska 1961, ryc. 19), 2-3 - stan obecny po rekonserwacji (ryc. i fot. A. Janowski) (opr. A. Janowski) 

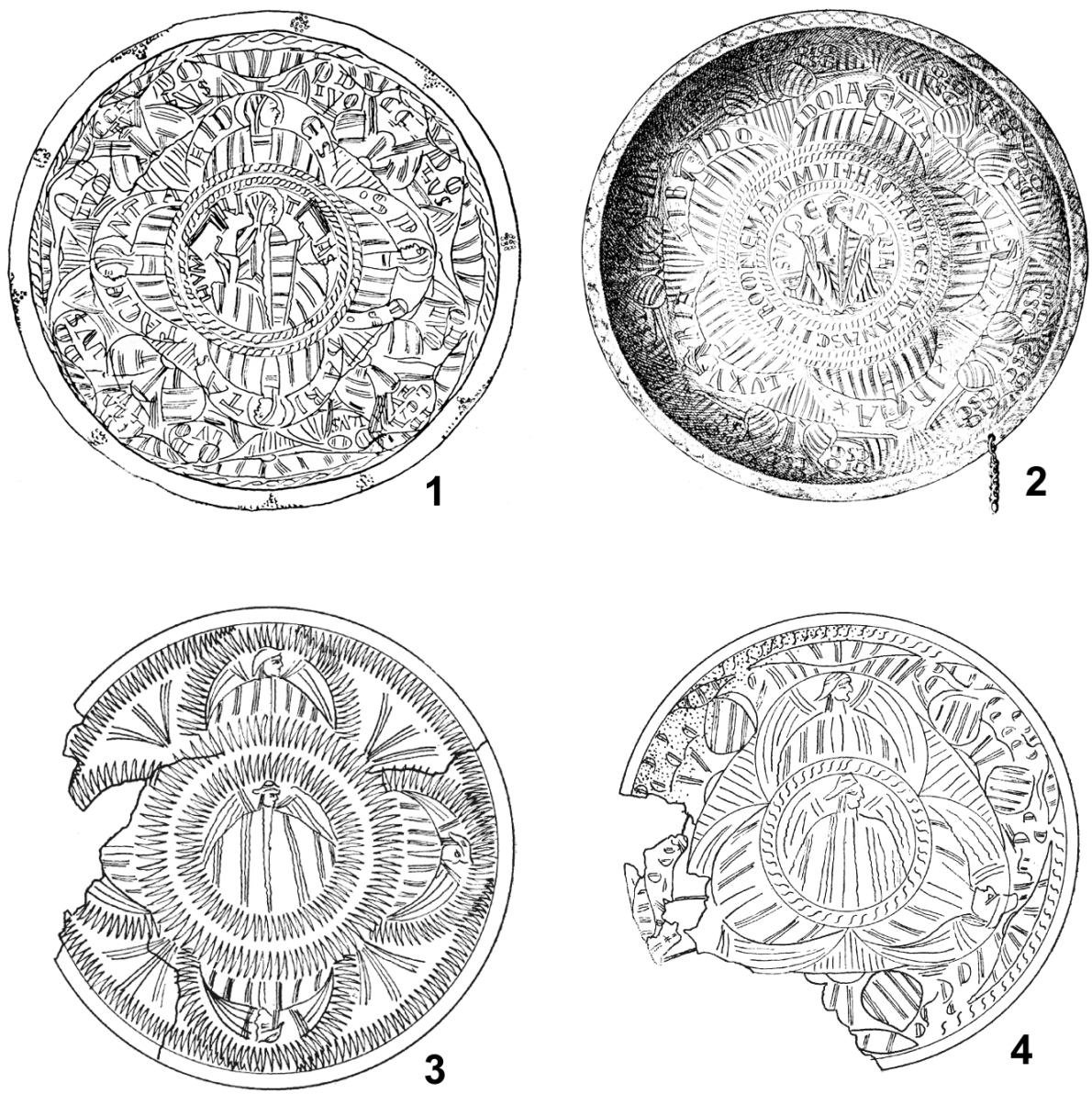

Ryc. 4. Przykłady mis z przedstawieniem cnót i występków (1-2) oraz „aniołów” (3-4) 1 - Lund (wg Poklewski 1961, tabl. XVI.b), 2 - Ryga (wg Pāvele 1964, att. 1), 3-4 - Sobótka (wg Poklewski 1961, tabl. XXI.a-b) (opr. A. Janowski)

przedmiotów ze stopów miedzi i wskazują na okres między drugą połową XI a końcem XIII w. jako czas, kiedy je wytwarzano.

Tadeusz Poklewski w swojej pracy na temat mis brązowych (1961), opierając się na różnicach w zdobiących je motywach, wydzielił sześć podstawowych typów, z których część podzielił dodatkowo na podtypy, na podstawie dalszych różnic stylistycznych. Biorąc pod uwagę sposób wykonania ornamentu na naczyniu z Santoka oraz czytelny na nim fragment inskrypcji, zaliczyć należy je do typu $\mathrm{IIb}$ - misy z personifikacjami pojęć o zeschematyzowanym rysunku (ryc. 4.1-2). Z kolei sposób przedstawienia szaty oraz nakrycie głowy centralnej postaci cha- 

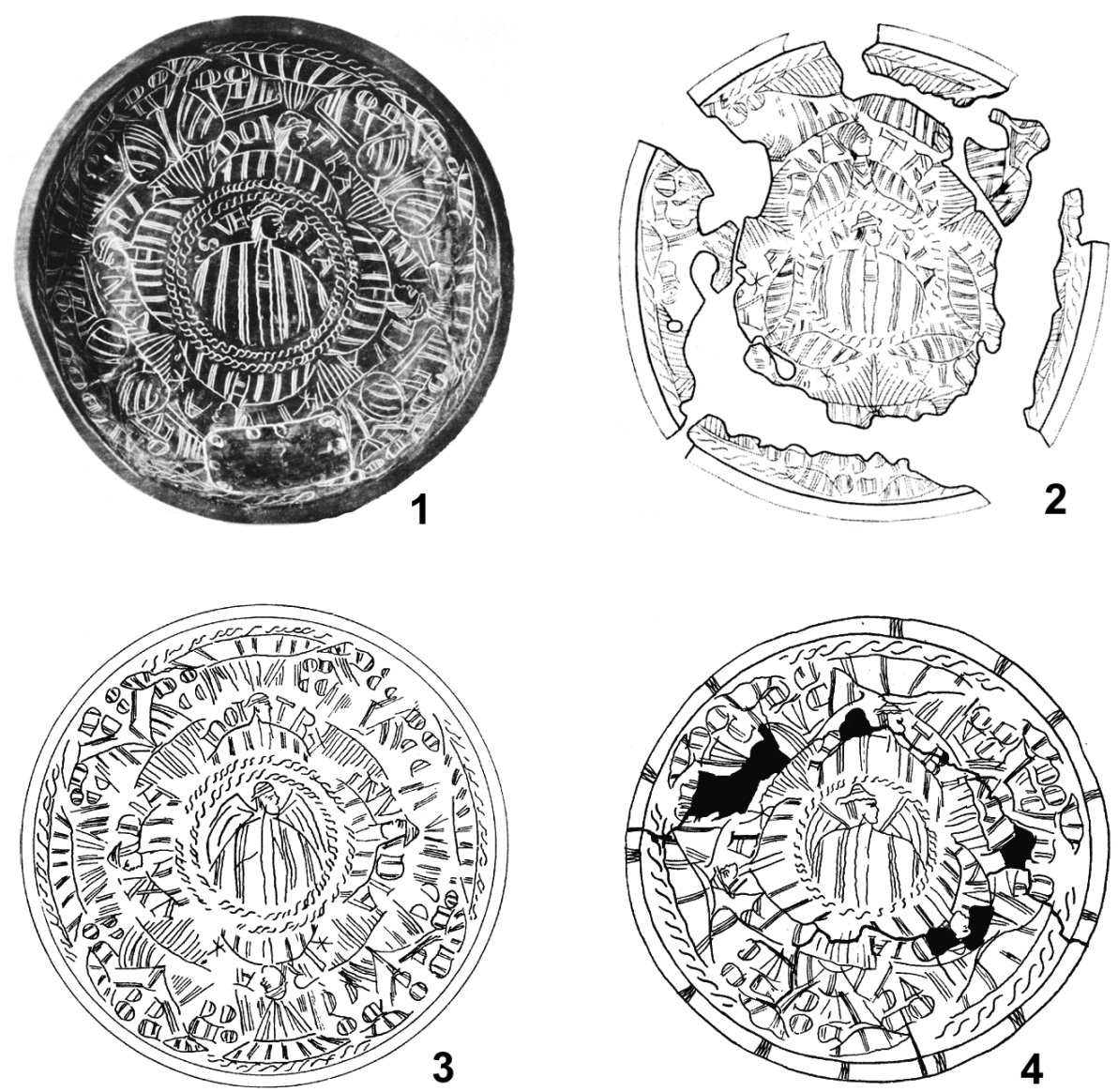

Ryc. 5. Przykłady mis o mieszanym typie zdobień: 1 - Neuenwalde (wg Bohls 1934); 2 - brak danych (zbiory w Brukseli - Müller 2006, Taf. 9.5-2), 3 - Rossum (wg Poklewski 1961, tabl XIX.b), 4 - Wierzchlas (wg Poklewski 1961, tabl. XXIV.a) (opr. A. Janowski)

rakterystyczne są dla naczyń typu III (ryc. 4.3-4). Na nich nie nanoszono jednak inskrypcji, dlatego nazywane są niekiedy „niemymi”. W klasyfikacji T. Poklewskiego misa santocka mieści się więc na granicy dwóch typów IIb i III.

Najnowsze studia przeprowadzone przez Ulricha Müllera (2006), na blisko czterokrotnie większym zbiorze niż dostępny T. Poklewskiemu, pozwoliły na bardziej szczegółowe rozwarstwienie typologiczne mis. Okaz santocki mieści się w typie B4 tej klasyfikacji (misy z przedstawieniem występków) (Müller 2006, s. 99). W tym liczącym dziś blisko 60 okazów zbiorze jest kilka naczyń wykazujących cechy zbliżone do misy santockiej. Co ciekawe, mieszany charakter ornamentu 


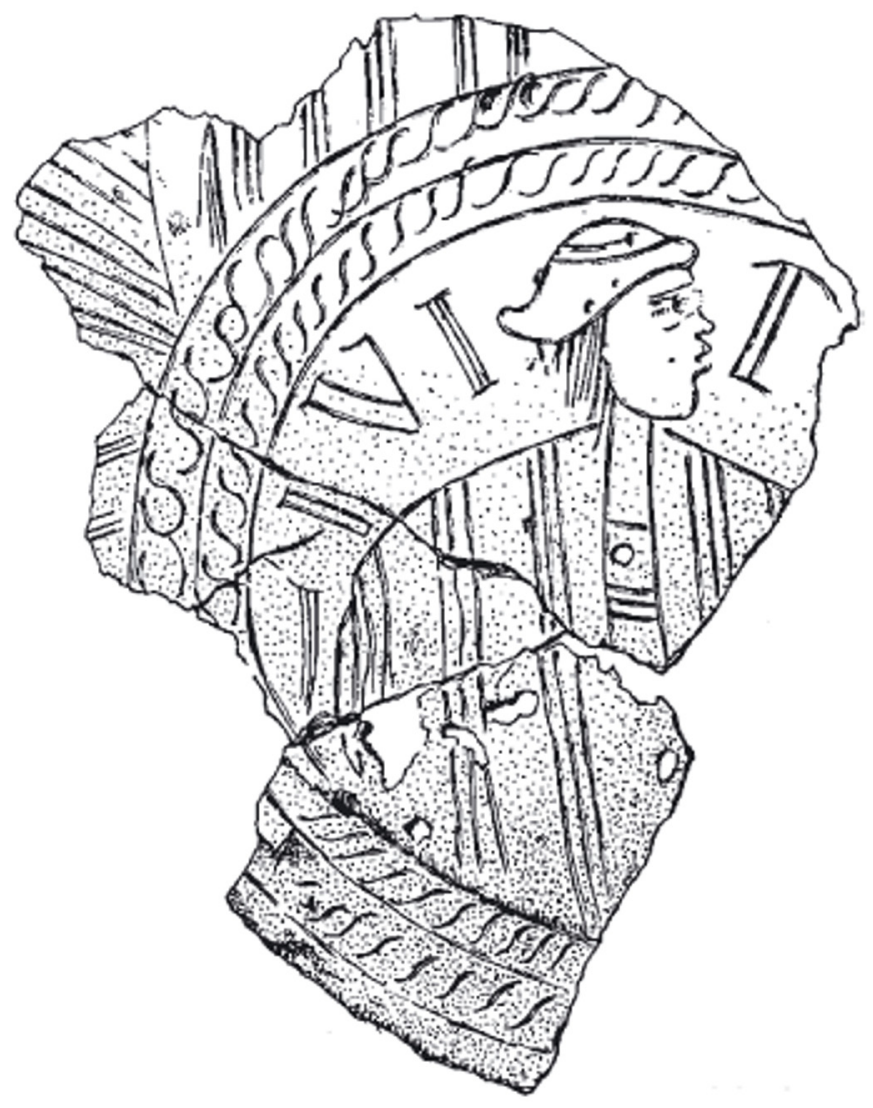

Ryc. 6. Misa brązowa z Allendorf (wg Schimpf 1981, Abb. 1)

wykazują wyłącznie misy ozdobione przedstawieniami występków. Mamy wśród nich misy zdobione w centrum „niemymi” uskrzydlonymi postaciami, a na ściankach personifikacjami grzechów i inskrypcjami o różnym stopniu barbaryzacji (np. Rossum - Poklewski 1961, tabl. XIX.b; Wierzchlas - Poklewski 1961, tabl. XXIV.a; Pusztavasad - Weitzmann-Fiedler 1981, nr 103; Ryga -Weitzmann-Fiedler 1981, nr 100; czy Lund - Weitzmann-Fiedler 1981, nr 101-102) (ryc. 5.3-4). Mamy także naczynia zdobione na dnie postaciami ukazanymi w sposób charakterystyczny dla mis typu III opisanymi jednak imieniem (np. Neuenwalde - Weitzmann-Fiedler 1981, nr 96; czy z muzeum w Brukseli - Weitzmann-Fiedler 1981, nr 97) (ryc. 5.1-2), czyli tak jak w omawianym przypadku. Najbliższą analogię do znaleziska santockiego stanowi fragmentarycznie zachowana misa $\mathrm{z}$ cysterskiego 


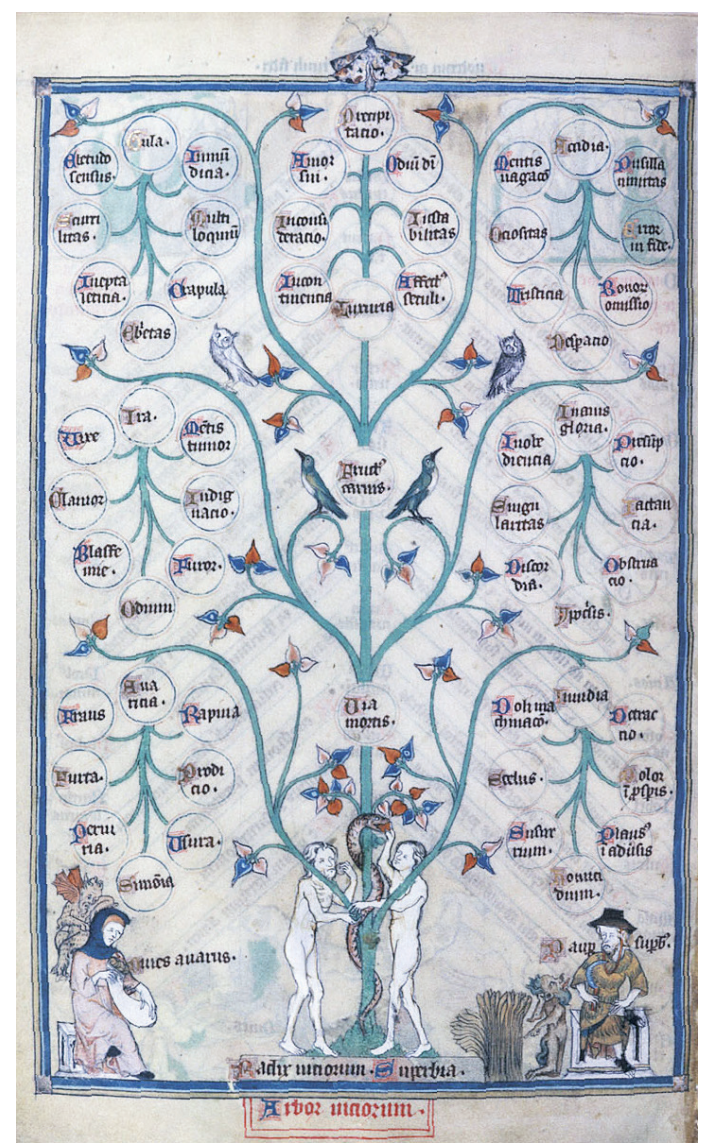

Ryc. 7. Drzewo genealogiczne występków (lata 1310-1320; MS. Arundel 83 II, fol. 128v, British Library; wg http:/www.bl.uk/catalogues/illuminatedmanuscripts/ILLUMINBig. ASP?size=big\&IllID=7111 - dostęp 19.01.2016)

klasztoru Allendorf w Bad Salzungen w Turyngii (zbudowany po 1265 r.) (Schimpf 1981, Abb. 1), która nie tylko zdobiona jest na dnie „bezskrzydłym aniołem”, ale i opisana słowem Invidia (ryc. 6).

Kompozycja ikonograficzna mis brązowych z przedstawieniem cnót i występków oparta była na ogół ${ }^{5}$ na zasadzie, że część centralną (dno) wypełniało przedstawienie jednej z cnót lub jednego z siedmiu grzechów głównych. Wokół, na ściankach naczynia, koncentrycznie rozmieszczone były kolejne, z nich wynikające lub nimi spowodowane. Układ taki nawiązywał do popularnego w ikonografii

5 Znamy kilka przykładów mis zdobionych jednocześnie przedstawieniami cnót i występków - por. Poklewski 1961, s. 33 . 


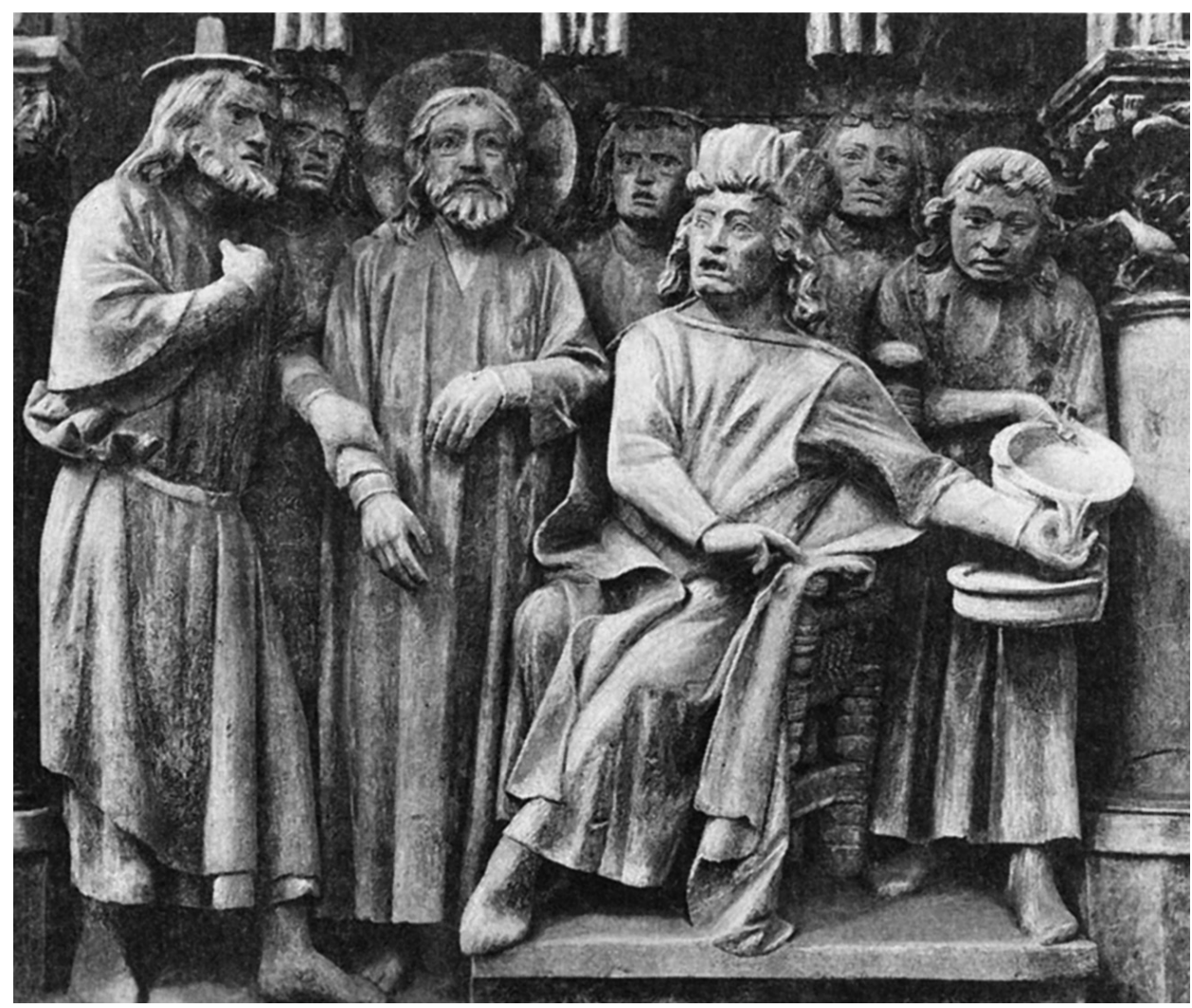

Ryc. 8. Piłat umywający ręce. Rzeźba z połowy XIII w. w lektorium katedry w Naumburgu (Hamann-Mac Lean 1950, Abb. 64)

motywu drzewa dobrych (arbor bona) i złych uczynków (arbor mala, arbor maorum) (por. Katzenellenbogen 1964, Taf. 39, abb. 65) ${ }^{6}$. W pierwszym przypadku $z$ humilitas (pokora) wyrastało drzewo, którego dolnymi konarami były cnoty kardynalne: prudentia (roztropność), iustitia (sprawiedliwość), temperantia (umiarkowanie) i fortitudo (męstwo), a koronę tworzyły cnoty teologalne, czyli fides (wiara), spes (nadzieja) i caritas (miłość). Z każdej z cnót wyrastały mniejsze gałązki zwieńczone liśćmi - siedmioma pomniejszymi cnotami. W przypadku grzechów układ graficzny był podobny, a hierarchia wyglądała następująco: korzeń (radix vitiorum) stanowiła superbia (pycha), z której wyrastały: avaritia (chciwość), invidia (zazdrość), a wyżej tzw. semita mortis tworzyły ira (gniew) i inanis gloria

${ }^{6} \mathrm{~W}$ przypadku niektórych mis brązowych w zdobnictwie wykorzystano motyw Psychomachii, czyli walki cnót i występków o duszę człowieka. Motyw ten pojawił się w literaturze na początku V w. za sprawą Aureliusza Prudentiusa Clemensa i właściwie nieprzerwanie do wieku XV wykorzystywany był w zdobnictwie kodeksów iluminowanych i architekturze - por. Norman 1988. 
(próżność), koronę (fructus carnis) wieńczyły gula (obżarstwo), acedia (lenistwo) i luxuria (pożądliwość) (ryc. 7). Z każdego z grzechów wyrastało siedem kolejnych. W przypadku zazdrości były to: malicia (złośliwość), odium (nienawiść), detractio (obmowa), susuratio (zniesławienie), amaritudo (rozgoryczenie), afflictio in prosperis (zazdrość cudzego dobrobytu), exultatio in adversis (radość z cudzych niepowodzeń) $)^{7}$.

Porządek grzechów nie był stały. Morton W. Bloomfield (1967, s. 59) wysunął hipotezę, że invidii nie było na pierwotnej liście grzechów, ponieważ ma ona związek z własnością, a ta nie była początkowo elementem pokuszenia. Tak jest chociażby u Ewagriusza z Pontu (345-399 r.) i Jana Kasjana (ok. 360-ok. 435 r.); w ich wykazach znalazło się po osiem występków: gula, luxuria, avaritia, ira, tristitia, acedia, inanis/vana gloria i superbia, ale brak w nich invidii. Wprowadził ją dopiero papież Grzegorz Wielki (ok. 540-604 r.), który w swoich Moraliach zredukował listę grzechów do siedmiu, dokonał też innych istotnych zmian - tristitiam zastąpiła acedia, a vana gloriam ustąpiła miejsca superbii (Brown 1998, 9-11). Po zmianach porządek grzechów wyglądał zatem następująco: superbia, ira, invidia, acedia, avaritia, gula, luxuria. Pierwsze pięć nazywane bywa duchowymi, a dwa ostatnie cielesnymi. Jak widać, invidia znalazła się na trzecim miejscu po pysze (superbia) i gniewie (ira). Porządek ten bywał jednak później zmieniany i zazdrość lokowano często na drugim miejscu. Mogło być to wynikiem zmiany światopoglądowej w średniowieczu wywołanej przestawieniem się modelu gospodarki z rolniczej na merkantylną. Powodowało to bogacenie się części społeczeństwa i wzrost zazdrości pozostałej, a tym samym niejako awans invidiae w hierarchii występków (por. Bloomfield 1967, s. 95-96; Meskill 2009, s. 48; Newhauser 2009). W 1215 r. IV sobór laterański nadał wspomnianej liście grzechów teologiczną podbudowę i nazwał śmiertelnymi, a za ich popełnienie groziły surowe kary (Marchese 2013, s. 360). Najpóźniej w XIII w. ukształtował się też porządek następujący: superbia (pycha), avaritia (chciwość), luxuria (pożądliwość), invidia (zazdrość), gula (obżarstwo), ira (gniew) i acedia (lenistwo). Akronim tworzył słowo SALIGIA, spopularyzowane przez włoskiego kardynała Enrico Segusio (1194-1271), które w okresie od połowy XIII do XVI w. wykorzystywano na określenie wszystkich grzechów łącznie (por. Watson 1947; Newhauser 2005; 2012, s. 159).

Przeświadczenie o znaczącej negatywnej roli superbiam wyrażała większość teologów. Szczególnie widoczne jest to w poglądach św. Augustyna (por. Green 1949; Favreau 1999), który napisał, iż „początkiem każdego grzechu jest pycha” - łac. Initium omnis peccati superbia. Zaowocowało to umieszczaniem personifikacji tejże na dnie mis, czyli w centrum kompozycji. U. Müller (2006, tab. 5)

\footnotetext{
${ }^{7}$ W Moraliach Grzegorza Wielkiego pomniejszych grzechów było pięć: odium, susurratio, detractio, exultatio in adversis proximi, afflictio autem in prosperis nascitur, a w Sumie Teologicznej św. Tomasza z Akwinu jedynie cztery: susurratio, exultatio in adversis, afflictio in prosperis oraz odium (por. St Thomas Aquinas 2006, s. 46-50).
} 
przeanalizował szczegółowo oprawę graficzną naczyń z przedstawieniem występków i stwierdził, że w przypadku 33 z 49 jemu znanych, w których możliwe było ustalenie kompozycji, w centrum umieszczono właśnie personifikację PYCHY (superbia), a po jednym razie NIEZGODY (discordia) i ZAZDROŚCI (invidia). Tak jest także w przypadku kilku kolejnych naczyń nieuwzględnionych przez U. Müllera (Bátmonostor-Pusztafalu - por. Biczó 1992, s. 88-91, 2 kep.a; Cleveland Cohen i Safran 2006, fig. 1; Malyj Kaup - por. Kulakov 2013, s. 135-136, ris. 7; Öcsöd - por. Szatmari 2014, s. 174-177). Na jednej z nich, z węgierskiego klasztoru Bátmonostor-Pusztafalu, umieszczoną centralnie superbiam otacza dodatkowo dookreślająca ją inskrypcja: Hac radice mala nascitur omne malum (,z tego złego korzenia wyrasta wszelkie zło”) (por. Biczó 1992, 2. kep. a). Sentencja ta, zaczerpnięta ze wspomnianych już Moraliów Grzegorza Wielkiego, znajduje się w otoku na dnie jeszcze ośmiu innych mis z przedstawieniem PYCHY (Ryga - Biczó 1992, przypis 7; Londyn - Weitzmann-Fiedler 1981, 96-97, nr 58; Tartu - Weitzmann-Fiedler 1981, 103-104, nr 80; Nurnberg - Weitzmann-Fiedler 1981, 107, nr 91; Nowy York - Weitzmann-Fiedler 1981, s. 107-108, nr 92; Minden - Weitzmann-Fiedler 1981, s. 108, nr 93; Hattem - Weitzmann-Fiedler 1983, s. 5-7; Arnhem - Weitzmann-Fiedler 1983, s. 7-8) (ryc. 4.2). Na tym tle fragmenty mis z Santoka i klasztoru Allendorf zdobione centralnie umieszczoną personifikacją invidiam jako grzechu głównego są nietypowe. Z drugiej jednak strony, choć nieumiejscowiona najwyżej w hierarchii ZAZDROŚĆ uważana była za jeden z najbardziej powszechnych, ale i najbardziej destrukcyjnych grzechów (Wenzel 1968; Balint 2007) ${ }^{8}$, a wywołane nią emocje mogły prowadzić zarówno do wielkich, jak i strasznych czynów.

W średniowiecznych źródłach brak informacji o sposobie wykorzystywania mis brązowych. W literaturze panuje jednak dość powszechne przekonanie, że mogły być one, zwłaszcza okazy zdobione przedstawieniami cnót i występków oraz cyklami mitologicznymi i chrześcijańskimi, wykorzystywane do obmywania rąk, np. w czasie obrzędów liturgicznych ${ }^{9}$, i pełniły funkcje edukacyjne w nowicjatach klasztornych, służąc kontemplacji mnichów (Poklewski 1961, s. 58-59; Weitzmann-Fiedler 1981, s. 9-17; Cohen i Safran 2006; Müller 2006, s. 204). Przesłanek do potwierdzenia pierwszej z przypisywanych im funkcji dostarczają przedstawienia Piłata umywającego ręce - m.in. rzeźba z połowy XIII w. z lektorium katedry w Naumburgu (por. Hamann-Mac Lean 1949-50, Abb. 64) (ryc. 8) czy wyobrażenia w XIII-wiecznych kodeksach (por. Müller 2006, Abb. 6, 8-9). Forma naczyń wykorzystanych przy tej czynności jest bardzo zbliżona do tej, jaką mają misy brązowe. W przypadku domniemanej funkcji edukacyjnej kwestia nie jest tak oczy-

\footnotetext{
8 Przykłady tego odnaleźć można także w wyobrażeniach na innych typach mis brązowych - por. Janowski 2008b.

${ }^{9}$ Nie był to zapewne chrzest, w średniowieczu przepisy nakazywały bowiem, by chrzcielnica wykonana była z kamienia - por. Kuczyńska 1981, s. 49-50.
} 
wista, zasadza się bowiem na założeniu, że jedynymi osobami zdolnymi zrozumieć przesłanie widocznych na misach przedstawień i inskrypcji były ówczesne elity intelektualne, czyli duchowieństwo. W zdobnictwie naczyń wykorzystano wszak elementy religijne, przeciwstawiające sobie chrześcijaństwo (np. cnoty, Samson) i pogaństwo (np. występki, Herkules) dodatkowo opisane cytatami z pism ojców kościoła (Grzegorz Wielki) czy podręczników szkolnych (Ekloga Theodulusa - por. Janowski 2008a).

Czy znalezisko santockie można powiązać z instytucją kościoła? Pierwsza wzmianka o tutejszym kościele pochodzi z Rocznika Kapituły Poznańskiej, gdzie pod rokiem 1270 zapisano informację o odbudowie grodu w Santoku: circa ecclesiam Sancti Andreae (KB 1961, s. 595). Taka wskazówka pozwala wysnuć wniosek o istnieniu świątyni w obrębie kompleksu grodowego, nie daje jednak wiedzy o miejscu usytuowania budowli. Powtórnie informacja o kościele w Santoku została przytoczona w Kronice wielkopolskiej zredagowanej w XIV wieku. Jest tam mowa o probostwie św. Andrzeja ulokowanym w grodzie santockim, podlegającym bezpośrednio biskupowi poznańskiemu i związanym z fundacją prepozycką (Kronika wielkopolska 2010, s. 201-202). Organizacja prepozytur była zjawiskiem charakterystycznym dla XII stulecia, a lokowano je przede wszystkim na terenach przygranicznych, gdzie odgrywały istotną rolę $\mathrm{w}$ administrowaniu terenami oddalonymi od centrum. Prepozyt santocki zarządzał z ramienia biskupa poznańskiego instytucjami kościelnymi na rozległym obszarze między Odrą, Iną, Drawą, Wartą i Notecią (KB 1961, s. 595; Jurek 2003, s. 293). Po zamordowaniu Przemysła II i przejęciu Santoka przez margrabiów brandenburskich tamtejsza prepozytura została zlikwidowana, a jej jurysdykcja przeniesiona na kapitułę w Myśliborzu. Wydarzenia te doprowadziły najpewniej do upadku kościoła santockiego i całkowitego rozebrania funkcjonującej tam kolegiaty. Ze źródeł pisanych znamy imiona niektórych prepozytów santockich, a ostatnia taka wzmianka pojawia się pod datą 4 sierpnia 1313 r., kiedy to wśród świadków podpisania układu kończącego spór o granice między cystersami Zemska i miastem Skwierzyną wystąpił Marsyliusz (Jurek 2003, s. 293; Rymar 2011, s. 54).

Nie znamy niestety okoliczności powstania kościoła w Santoku, nie donoszą o tym źródła pisane. Także badania archeologiczne nie dostarczyły dotąd jednoznacznych dowodów poświadczających miejsce ulokowania i datowanie pierwszego kościoła. Prace przeprowadzone przez badaczy niemieckich w latach 1932-1934 ujawniły obecność w północnej części grodziska cmentarza oraz reliktów kamiennej budowli. Zachowały się pozostałości murów i kamiennego fundamentu szerokości około $2 \mathrm{~m}$, będącego podwaliną budowli prostokątnej o wymiarach w świetle 7,5 m i szerokości 5,5 m. Budowla mogła w kolejnym etapie ulec przebudowie, na co wskazuje pośrednio także obecność warstw budowlanych zarejestrowana w obrębie sąsiadującego z reliktami cmentarza (Hensel i Hilczer-Kurnatowska 1987, s. 26). Zakończenie budowli od strony wschodniej, ze względu na słaby stan zachowania budowli, jest trudne do rekonstrukcji. W trakcie prac archeologicznych 
oprócz fundamentów kamiennych odsłonięto również część cmentarza - ponad 40 grobów ułożonych rzędowo, w niektórych miejscach warstwowo. Zmarli, w dominującej części bez elementów wyposażenia, zostali złożeni do grobów w pozycji na grzbiecie, z głową skierowaną na zachód i przeważnie z rękami wyprostowanymi wzdłuż ciała (Hensel i Hilczer-Kurnatowska 1987, s. 25-26, ryc. 4). Rozlokowanie grobów wokół kamiennej budowli oraz orientacja pochówków i ich regularny układ sugerują, iż natrafiono wówczas na relikty kościoła wraz z cmentarzem przykościelnym. Mógł to być wspomniany w źródłach pisanych kościół św. Andrzeja, który został rozebrany po zniesieniu prepozytury i następnie przekształcony w budowlę o charakterze świeckim. Na teren cmentarza wybrano wtedy miejsce na zniszczonym przez pożar i zniwelowanym, wschodnim odcinku wału otaczającego gród wewnętrzny. W opracowaniu z badań niemieckich zawarta jest informacja, iż obrobione ciosy granitowe zostały wtórnie użyte przy wznoszeniu kolejnych budynków w XIV i XV stuleciu (Hołowińska 1961, s. 50).

Rozpatrując możliwości usytuowania kościoła św. Andrzeja w obrębie grodu santockiego, należy również wziąć pod uwagę kamienne relikty budowli znalezione w południowej części dawnego grodu, odsłonięte w trakcie badań archeologicznych związanych z projektem „Millenium”, przeprowadzonych w Santoku w latach 1958-1965. Zarejestrowano wówczas fragment rowu fundamentowego w formie narożnika, o szerokości 2,3 m i przekroju nieckowatym o maksymalnej głębokości 0,7 m, wypełnionego częściowo obrabianymi kamieniami, bez śladów łączenia zaprawą wapienną (jej grudki zarejestrowano jedynie w znikomej ilości w otoczeniu fundamentu). Przebieg fundamentu (orientacja ściany po linii północ-południe) i układ konstrukcji wskazywały, że mógłby to być grodowy kościół wczesnoromański wstępnie datowany na czasy ottońskie (druga połowa $\mathrm{X}$ - pierwsza połowa XI wieku). Ślady kolejnych regularnie układających się rowów wypełnionych kamieniami odsłonięte w sąsiedztwie wspomnianego wcześniej narożnika fundamentu mogą świadczyć o kolejnej inwestycji architektonicznej prowadzonej w tym miejscu.

Wyjaśnienie kwestii kościoła grodowego w Santoku wymaga dalszych badań, choć samo jego funkcjonowanie w tym ośrodku w XII i XIII stuleciu wydaje się pewnie poświadczone. Niewykluczone, że to z nim i sprawującymi tam posługę duchownymi wiązać należy obecność misy brązowej z przedstawieniami występków.

\section{PROFANUM - ŻYWOT DRUGI}

Santocka misa nie dotrwała do naszych czasów w całości, ale w stanie pofragmentowanym. Wyraźne, proste krawędzie zachowanego ułamka świadczą o tym, iż został on intencjonalnie wycięty. Dzięki widocznemu na nim ornamentowi i inskrypcji wiemy, jakiego przedmiotu fragmentem była pierwotnie ta blaszka. Moż- 
na mówić w tym przypadku o dużym szczęściu, archeologia ma bowiem często problem z identyfikacją drobnych, zniekształconych przedmiotów, a co dopiero ze stwierdzeniem, czy pierwotnie stanowiły one element innej, większej całości. Ślady celowego odcinania rozpatrywać należy zapewne w charakterze recyklingu, czyli działań zmierzających do powtórnego przetwarzania substancji, materiału lub przedmiotu w celu odzyskania/uzyskania substancji, materiałów lub przedmiotów o tym samym lub innym przeznaczeniu. Metale doskonale się do tego nadawały (por. Baumeister 2004). Już w Historii naturalnej autorstwa Gajusza Pliniusza Starszego (I w. n.e.) znalazły się zalecenia, by przy wytopie stosować złom miedziany, który ze względu na wcześniejsze oczyszczenie ze szkodliwych domieszek wpływał korzystnie na „oswojenie” stopu (por. Piaskowski 1957, s. 111). W przypadku, gdy na jakimś terytorium nie było naturalnych źródeł danego surowca, cała produkcja musiała być, siłą rzeczy, oparta albo na jego imporcie, albo na wtórnym wykorzystaniu dostępnych przedmiotów (por. Fleming 2012).

W średniowieczu praca człowieka nie była wiele warta, w przeciwieństwie do surowca, którego brakowało. Dlatego też każdy przedmiot, o ile nie uległ nieodwracalnej degradacji, zagubieniu lub wyłączeniu $\mathrm{z}$ obiegu $\mathrm{z}$ innych powodów (skarb, dar grobowy), starano się ponownie wykorzystać. W tym kontekście przykłady wtórnego wykorzystania blachy mis brązowych nie należą do wyjątków (por. Janowski 2009, tu starsza literatura). Problemem pozostaje ich identyfikacja, w przypadku gdy na powierzchni brak charakterystycznego ornamentu.

Powtórnej obróbki przedmiotów metalowych dokonywano zarówno na gorąco - przetapiając metal (działania w praktyce prawie niemożliwe do zaobserwowania przez archeologa), ale także na zimno, np. wycinając mniejsze fragmenty blachy i wykonując z nich podkładki, okucia czy nity. Można podejrzewać, że w średniowieczu przy klasztorach istniały warsztaty czy kuźnie, w których wykonywano takie czynności. Jako przykład można wskazać tu chociażby klasztor Norbertanów w Białobokach koło Trzebiatowa (por. Janowski 2015) ${ }^{10}$.

Miejsca takie funkcjonowały także w znaczniejszych ośrodkach życia społeczno-gospodarczego. O istnieniu pracowni kowalskich w ośrodkach średniowiecznych, poza miastami, świadczą pozostałości warsztatów (głównie paleniska, narzędzia kowalskie, surowiec, odpady produkcyjne czy półprodukty) znajdowane również $\mathrm{w}$ miejscach lokowania dawnych rycerskich siedzib mieszkalno-obronnych. Palenisko kowalskie rozpoznano w Siedlątkowie (Kamińska 1968, s. 41-43; Nosek 1968). W piwnicy wieży z XIV w. odsłonięto gliniany piec kopułowy o średnicy $2 \mathrm{~m}$. Wokół pieca znaleziono liczne półprodukty oraz narzędzia kowalskie (cęgi, gwoździownica, przecinaki). Podłogę kuźni stanowiło klepisko. Istnienie podobnych urządzeń i warsztatów potwierdzone jest jeszcze w kilku grodach i osadach z XIII-XV wieku. W kujawskiej Zgłowiączce pod wałem we wschodniej

${ }^{10} \mathrm{Z}$ przykładów zachodnioeuropejskich wymienić można chociażby warsztat odsłonięty obok klasztoru benedyktyńskiego w Saalfeld w Turyngii (por. Spazier 2012, s. 349-353). 
części grodu odkryto dwa piece, a wraz z nimi bryły żużla i fragmenty przedmiotów żelaznych. Wszystko datowane na 2-3 ćwierć XIII w. (Andrzejewska 2011, s. 557-558). W mazowieckim Czersku z kolei w części południowo-wschodniej założenia z XIII w. ujawniono fragment dyszy ze skupiskiem łupy i żużli, naczynie zawierające stopiony metal oraz toczydło do ostrzenia narzędzi i broni (Kiersnowska 1986, s. 83). Na pozostałości interpretowane jako pracownia kowalska natrafiono także w Międzyrzeczu w Wielkopolsce. W nawarstwieniach grodu z fazy zasiedlenia datowanej na przełom XIII/XIV - pierwszą połowę XIV w. odsłonięto palenisko, a wokół niego przedmioty żelazne gotowe i półfabrykaty (Banach i in., 2015, s. 238-239). W nieodległej Nowej Wsi na wschodnim skraju osady z XV w., blisko rzeki odkryto wkopany w grunt obiekt ( $\mathrm{nr} 100$ ) o wymiarach $7 \times 3 \mathrm{~m} \mathrm{z}$ kamienno-glinianym piecem kopułowym oraz narzędziami kowalskimi i fragmentami przedmiotów metalowych (Dzieduszycki, Makiewicz i Sobucki 1998, s. 173, ryc. 38-39). W przypadku przytoczonych przykładów kuźni odkryte relikty potwierdzają na ogół obróbkę termiczną żelaza. Odmiennym, a w kontekście poruszanych w artykule zagadnień niezwykle istotnym przykładem jest pracownia odsłonięta na grodzisku w Raciążu na Pomorzu. Odkryto w niej fragmenty mis brązowych w różnych stadiach destrukcji, okucia z blachy brązowej, a także przetopione półprodukty do wykonywania blachy i zreperowane naczynia. Kolejne fragmenty mis odkryto w przylegających budynkach (Kowalczyk 1976; 1986, s. 70-71, 73, tabl. XLVII.c, e-f, XLIX).

W Santoku także znaleziono obiekt, który można interpretować jako pozostałości pracowni kowalskiej. W miejscu silnie zniwelowanego wału, w jego dawnej partii szczytowej i częściowo skłonie zewnętrznym zachowało się palenisko oraz podwaliny budynku drewnianego, zalegające w nawarstwieniach przesiąkniętych żużlem, z przepaloną gliną i grudkami rudy darniowej oraz dużą liczbą przedmiotów metalowych zachowanych głównie fragmentarycznie.

Do obiektu nazwanego kuźnią zaliczono piec wraz z warstwami go otaczającymi, a także pozostałości po dwóch belkach stanowiących południową ścianę budynku, usytuowanego na osi wschód-zachód. Piec miał w przybliżeniu okrągły kształt. Palenisko składało się z pięciu warstw silnie skruszałych, przepalonych kamieni o średnicy od 5 do $20 \mathrm{~cm}$, spojonych gliną przepaloną na kolor pomarańczowy. Uwagę zwracał nieckowaty układ kamiennego dna, które można interpretować jako pozostałość kotlinki będącej nieodłączną częścią pieców do przerobu rudy darniowej i wytopu żelaza. Dookoła paleniska zarysował się otok z jasnego, przepalonego piasku oraz spalenizny. Średnica opisanej konstrukcji wynosiła 1,90 × 2,00 m (dokumentacja dostępna w Archiwum IAE PAN Ośrodek w Poznaniu). W nawarstwieniach tych zalegały liczne, zachowane głównie we fragmentach, przedmioty żelazne i brązowe: gwoździe, noże, haki, siekiery, blachy i misy żelazne, klucze, wagi oraz bryłki żelaza, żużla i rudy (w sumie 47 przedmiotów metalowych). Oprócz tego w warstwie znaleziono grzebień kościany i półfabrykaty z poroża. 
Przedstawione relikty mogły stanowić pozostałość pieca, ale jego przeznaczenie trudno ostatecznie określić. Bardzo prawdopodobne, iż używano go nie do wytapiania rudy darniowej, ale do przetopu uzyskanej z niej wcześniej łupy żelaznej. W takim przypadku kawałki surowca wytapiano w glinianych tyglach lub garnkach wraz z węglem drzewnym, ustawiając naczynia na dnie pieca. Takie łupy żelazne przekuwano również mechanicznie. Rudę można było przerabiać blisko miejsca pozyskiwania, gdzie oczyszczano ją i rozdrabniano, a następnie wytapiano w pie$\mathrm{cu}$, w efekcie czego otrzymywano surowiec do dalszej obróbki - łupę. W kolejnym etapie, który mógł odbywać się już bliżej osiedla, w przygotowanym piecu następował proces oczyszczania aż do momentu uzyskania żelaza kowalnego. Prace związane z pozyskiwaniem surowca miały charakter sezonowy, a jeden wytwórca mógł być zarówno hutnikiem, jak i kowalem.

W Santoku, w nawarstwieniach stanowiących kontekst kuźni, nie znaleziono pozostałości narzędzi czy tygli i naczyń nawiązujących bezpośrednio do funkcji tego obiektu. Jedynym przedmiotem, który można łączyć z produkcją metalurgiczną, jest znaleziona (warstwa Ib) w sąsiedztwie domniemanej kuźni dysza gliniana (nr inw. 460/59). Częściowo uszkodzona, gliniana dysza ma formę cylindra o średnicy około $25 \mathrm{~mm}$ i zachowanej długości $43 \mathrm{~mm}$. Przedmiot ten nierozerwalnie łączy się z kuźnią. Dysze pełniły funkcję elementów łączących miech kowalski z piecem. Umożliwiały wtłoczenie do ogniska silnego strumienia powietrza, ale również zabezpieczały miech przez bezpośrednim kontaktem z ogniem, pełniąc rolę izolującą. Pojedyncze znaleziska glinianych dysz do miechów znane są zarówno ze stanowisk pradziejowych, jak i średniowiecznych. Przez badaczy łączone są z lokalną wytwórczością metalurgiczną żelaza i metali nieżelaznych. Podobne przedmioty, datowane na okres średniowieczny, zostały znalezione m.in. na podgrodziu w Kruszwicy (Hensel-Moszczyńska 1983, s. 130; tabl. VII-1, XIII-1). Na jednej z tych dysz były widoczne ślady metali: miedzi i ołowiu.

Kuźnię w Santoku, na podstawie danych stratygraficznych i materiału archeologicznego możemy datować na XIV stulecie. Jej obecność w sąsiedztwie usytuowanej w północno-zachodniej części dawnego grodu wieży obronnej na kopcu uzasadnia także dostępność surowca - złóż rud zalegających w okolicach Santoka na podmokłych terenach w dolinie Warty-Noteci (Rutkowski 2001). Fragment pociętej misy odkryto w niewielkiej odległości od zniszczonej kuźni, w nawarstwieniach zawierających jej destrukt, na zachód od pieca. Niewykluczone zatem, że łączyć należy jego obecność w tym miejscu z jej działalnością i wtórną obróbką przedmiotów metalowych w celu naprawy, adaptacji lub dalszego wykorzystania.

\section{ZAKOŃCZENIE}

Opisana w tekście historia to przykład biografii przedmiotu, który zapewne w XII w. powstał gdzieś na obszarze Nadrenii, skąd w bliżej nieokreślonym czasie 
dotarł na teren Santoka. Można podejrzewać, że służył tutaj do sprawowania obrzędów liturgicznych, a gdy uległ zniszczeniu lub przestał być potrzebny, jego pierwszoplanowa funkcja uległa zmianie. Trafił do pracowni kowalskiej, gdzie został pocięty z myślą o dalszym wykorzystaniu wciąż tkwiącego w nim potencjału - kosztownej mosiężnej blachy.

\section{LITERATURA}

Andrzejewska A. 2011, Jeszcze o średniowiecznej kuźni ze Zgłowiączki na Kujawach, w: O. Ławrynowicz, J. Maik i P.A. Nowakowski (red.), Non Sensistis Gladios. Studia ofiarowane Marianowi Głoskowi w 70. rocznice urodzin, Łódź, s. 557-564.

Balint B.K. 2007, Envy in the intellectual discourse of the High Middle Ages, w: R. Newhauser (red.), The Seven Deadly Sins. From Communities to Individuals, Leiden-Boston, s. 41-55.

Banach B. i in. 2015, Gród i zamek późnośredniowieczny, w: S. Kurnatowski (red.), Międzyrzecz. Gród i zamek $w$ wiekach IX-XIV. Wyniki prac wykopaliskowych z lat 1954-1961, Warszawa, s. 217-278.

Baumeister M. 2004, Metallrecycling in der Frühgeschichte. Untersuchungen zur technischen, wirtschaftlichen und gesellschaftlichen Rolle sekundärer Metallverwertung im 1. Jahrtausend n. Chr., „Würzburger Arbeiten zur Prähistorischen Archäologie” 3, Rahden.

Biczó P. 1992, Román kori táltöredékek Bátmonostorról, „Cumania” 13, s. 87-112.

Bloomfield M.W. 1967, The Seven Deadly Sins. An Introduction to the History of a Religious Concept, with the Special Reference to Medieval English Literature, Michigan.

Bohls J. 1934, Die Metallschale aus dem Moor bei Neuenwalde, Niederdeutsches Heimatblatt 3 (Juli).

Brown J. 1998, The Seven Deadly Sins in the Work of Dorothy L. Sayers, Kent.

Cohen A.S., Safran L. 2006, Learning from Romanesque bronze bowls, „Word and Image” 22 (3), S. 211-218.

Dodwell C.R. 1961, The Various Arts. De Diversis Artibus, Oxford.

Droberjar E., Frána J. 2004, Antická mosaz (aurichalcum) v českých nálezech časné doby řimské, „Archeologie ve středních Čechách” 8 (1), s. 441-462.

Dymaczewski A. 1975, Die Ausgrabungen in Santok - Ergebnisse und Fragen der Weiterführung der Forschungen, „Archaeologia Polona” 16, s. 231-238.

Dzieduszycki W., Makiewicz T. i Sobucki A. 1998, Nowa Wieś, st. 1 i 12, w: R. Mazurowski (red.), Archeologiczne badania ratownicze wzdluż trasy gazociagu tranzytowego 1. Ziemia Lubuska, Poznań, s. 117-181.

Favreau R. 1999, Initium omnis peccati superbia (Ecclésiastique, X, 15), w: R. Favreau, M.-H. Debiès (red.), Iconographica: mélanges offerts à Piotr Skubiszewski/par ses amis, ses collègues, ses élèves, Poitiers, s. 91-100.

Fleming R. 2012, Recycling in Britain after the Fall of Rome's Metal Economy, „Past and Present” 217, s. $3-45$.

Freise E. 1981, Roger von Helmarshausen in seiner monastischen Umwelt, „Frühmittelalterliche Studien" 15 , s. 180-293.

Green W.M.A. 1949, Initium omnis peccati superbia. Augustine on Pride as the First Sin, „Classical Philology" 13, s. 407-432.

Hamann-Mac Lean R.H.L. 1950, Antikenstudium in der Kunst des Mittelalters, „Marburger Jahrbuch für Kunstwissenschaft”'15, s. 157-250.

Hensel W. i Hilczer-Kurnatowska Z. 1987, Studia i materialy do osadnictwa Wielkopolski wczesnohistorycznej 6, Wrocław.

Hensel-Moszczyńska B. 1983, Wyroby z miedzi i jej stopów z wczesnośredniowiecznej Kruszwicy, „Slavia Antiqua" 28, s. 127-221.

Hołowińska Z. 1961, Dzieje wczesnośredniowiecznego grodu w Santoku w VII/VIII do XIII wieku, w: U. Dymaczewska i Z. Hołowińska, Z dziejów Santoka i kasztelanii santockiej. Poznań, s. 22-52. 
Janowski A. 2008a, The bronze bowl from Nowe Objezierze - archaeological contribution to the history of intellectual culture in medieval Western Pomerania, w: M. Bogucki, M. Franz i Z. Pilarczyk (red.), Kultura ludów Morza Baltyckiego, t. 1. Starożytność i średniowiecze, Mare Integrans. Studia nad dziejami wybrzeży Morza Battyckiego, Torun, s. 140-160.

- 2008b, Zazdrość i pożądanie jako choroby śmiertelne. Przykład Heraklesa, w: W. Dzieduszycki i J. Wrzesiński (red.), Epidemie, klęski, wojny, „Funeralia Lednickie. Spotkanie” 10, Poznań, s. $317-319$.

- 2009, Recykling metali w średniowieczu. Kilka uwag o wtórnym wykorzystaniu średniowiecznych mis brazowych, w: M. Bogucki, M. Franz i Z. Pilarczyk (red.), Gospodarka ludów Morza Bałtyckiego, t. 1. Starożytność i średniowiecze, Mare Integrans. Studia nad dziejami wybrzeży Morza Battyckiego, Toruń, s. 117-132.

- 2015, Zabytki ruchome, w: M. Rębkowski i F. Biermann (red.), Klasztor premonstratensów w Biatobokach. Archeologia i historia, Szczecin, s. 105-127.

Jurek T. 2003, Santok, w: A. Gąsiorowski (red.), Stownik historyczno-geograficzny województwa poznańskiego w średniowieczu 4 (2), Poznań, s. 286-299.

Kamińska J. 1968, Siedlątków, obronna siedziba rycerska z XIV wieku, „Prace i Materiały Muzeum Archeologicznego i Etnograficznego w Łodzi", Seria Archeologiczna 15, s. 15-88.

Katzellenbogen A. 1964, Allegories of the Virtues and Vices in Mediaeval Art. From Early Christian Times to the Thirteenth Century, New York.

Kiersnowska T. 1986, Czersk w XIII i XIV wieku. Ośrodek władzy książęcej na poludniowym Mazowszu, Warszawa.

Kowalczyk M. 1976, Średniowieczna pracownia kowalska na grodzie w Raciązu, pow. Tuchola, „Acta Universitatis Lodziensis", Nauki humanistyczno-społeczne 11, s. 59-74.

- 1986, Raciąż - średniowieczny gród i kasztelania na Pomorzu w świetle źródet archeologicznych i pisanych, „Archaeologia Baltica” 6, Łódź.

KB 1961, Kronika Boguchwata i Godysława Paska, opr. W.A. Maciejowski, w: A. Bielowski (wyd.), „Monumenta Poloniae Historica” 2, Warszawa, s. 454-598.

Kronika wielkopolska 2010, Przekład Kazimierz Abgarowicz, Kraków.

Kuczyńska J. 1981, Chrzcielnica w świetle myśli liturgicznej i przepisów kościelnych średniowiecza, „Roczniki Humanistyczne” 29 (4), s. 49-58.

Kulakov V.I. 2013, Malyj Kaup: dve formy obrâdnosti, „Pruthenia” 8, s. 127-147.

Marchese F.T. 2013, Virtues and Vices: Examples of Medieval Knowledge Visualization, w: Proceedings of the 17th International Conference on Information Visualization: IV'13 (London, UK, July 16-18, 2013), Los Alamitos, s. 359-365.

Meskill L.S. 2009, Ben Jonson and Envy, Cambridge.

Müller U. 2006, Zwischen Gebrauch und Bedeutung. Studien zur Funktion von Sachkultur am Beispiel mittelalterlichen Handwaschgeschirrs (5./6. bis 15./16. Jahrhundert), „Zeitschrift für Archäologie des Mittelalters", Beiheft 20, Bonn.

Newhauser R. 2005, Introduction, w: R. Newhauser (red.), In the Garden of Evil: The Vices and Culture in the Middle Ages, Toronto, VII-XIX.

- 2009, The Capital Vices as Medieval Anthropology, w: Ch. Flüeler, M. Rohde (red.), Laster im Mittelalter. Vices in the Middle Ages, Berlin-New York, s. 105-124.

- 2012, "These Seaven Devils": The Capital Vices on the Way to Modernity, w: R. Newhauser, S.J. Ridyard (red.), Sin in Medieval and Early Modern Culture. The Tradition of the Seven Deadly Sins, Woodbridge, s. 157-188.

Norman J.S. 1988, Metamorphoses of an Allegory: The Iconography of the Psychomachia in Medieval Art, New York.

Nosek E. 1968, Czternastowieczna kuźnia w Siedlatkowie, „Prace i Materiały Muzeum Archeologicznego i Etnograficznego w Łodzi”. Seria Archeologiczna 15, s. 95-132.

Pāvele T. 1964, Latvijas 11-13 gs. bronzas blodas, „Arheolog̣ija un etnogrāfija” 6, s. 127-134.

Piaskowski J. 1957, Metalurgia w „Historii naturalnej” G. Pliniusza Starszego, „Archeologia” 9, s. 99-122.

Poklewski T. 1961, Misy brazowe z XI, XII i XIII wieku, „Acta Archaeologica Universitatis Lodziensis” 9. Łódź. 
Richter G. 1951, Romanische Kleinbronzen in Stendal, Altmärkisches Museum Stendal Jahresgabe für 1951 (4), s. 1-58.

Rutkowski M. 2001, Żelazne łąki, „Wiedza i Życie” 5 (archiwum.wiz.p1/2001/01050500.asp).

Rymar E. 2011, Jurysdykcja kościelna na ziemiach pogranicza pomorsko-wielkopolskiego. Archidiakonaty nowomarchijskie (XIV-XV w.), „Nadwarciański Rocznik Historyczno-Archiwalny” 18, s. 45-68.

Schimpff V. 1981, Eine Hanseschüssel aus Thüringen, „Ausgrabungen und Funde” 26 (5), s. 251-255.

Spazier I. 2012, Saalfeld/Thüringen - Die Entwicklung von der Königspfalz zum Benediktinerkloster St. Peter und Paul vom 10. bis 13. Jahrhundert, w: F. Biermann i in. (red.), Transformationen und Umbrüche des 12./13. Jahrhunderts, „Beiträge zur Ur- und Frühgeschichte Mitteleuropas” 64. Langenweißbach, s. 335-356.

St Thomas Aquinas 2006, Summa Theologiae 35 (2a2ce. 34-36), Cambridge.

Szatmári I. 2014, Árpád-kori fémtálak Békés megyei gyüjteményekben, „Archaeologiai Értesítő” 139, s. $171-192$.

Teofil 1998, Teofil Prezbiter. Diversarum Artium Schedula. Średniowieczny zbiór przepisów o sztukach rozmaitych, thum. i oprac. S. Kobielus, Kraków.

Trotzig G. 1991, Craftsmanship and function. A study of metal vessels found in Viking Age tombs on the island of Gotland, Stockholm.

Watson A. 1947, Saligia, „Journal of the Warburg and Courtauld Institutes” 10, s. 148-150.

Werner O. 1977, Analysen mittelalterlicher Bronzen und Messinge I, „Archäologie und Naturwissenschaften" 1, s. 143-220.

- 1981, Analysen mittelalterlicher Bronzen und Messinge II und III, „Archäologie und Naturwissenschaften" 2, s. 106-170.

Weitzmann-Fiedler J. 1981, Romanische gravierte Bronzeschalen, Berlin.

Weitzmann-Fiedler J. 1983, Romanische gravierte Bronzeschalen, Nachträge zu dem 1981 erschienenen Werk, „Zeitschrift des deutschen Vereins für Kunstwissenschaft” 37 (1-4), s. 1-21.

Wenzel S. 1968, The Seven Deadly Sins: Some Problems of Research, „Speculum” 43 (1), s. 1-22.

Wołosz A.K. 1994, rec. Jadwiga Kuczyńska, Mosiężne misy norymberskie, „Kwartalnik Historii Kultury Materialnej" 42 (1), s. 110-114.

Praca naukowa finansowana w ramach programu Ministra Nauki i Szkolnictwa Wyższego pod nazwą „Narodowy Program Rozwoju Humanistyki” w latach 2012$-2017$.

Tytuł projektu: „Regni custodiam et clavem - Santok i clavis regni Poloniae - Milicz jako przykład dwóch grodów granicznych. Przygotowanie bazy źródłowej do przeprowadzenia archeologiczno-historycznego studium porównawczego"; $\mathrm{nr} 11 \mathrm{H} 11$ 018480. Kierownik projektu: prof. dr hab. Zofia Hilczer-Kurnatowska (2012-2013), dr Kinga Zamelska-Monczak (2013-2017). 
